\title{
FORUM-SELECTION BYLAWS REFRACTED THROUGH AN AGENCY LENS
}

\author{
Deborah A. DeMott ${ }^{*}$
}

Both praise and controversy surround director-adopted bylaws that affect shareholders' litigation rights. Recent bylaws specify an exclusive forum for litigation of corporate governance claims, limit shareholder claims to resolution through arbitration, and (most controversially) impose a one-way regime of fee shifting on shareholder litigants. To one degree or another, courts have legitimated each development, while commentators differ in their assessments. This Article brings into clear focus issues so far blurred in debates surrounding these types of bylaws. Focusing on forum-selection bylaws, and on Delaware precedents, I argue that beginning from the standpoint of common law agency reveals the attenuated and incoherent concept of consent underlying forumselection bylaws when they are unilaterally adopted by directors once shareholders have invested in a firm.

In particular, the concept of a "flexible contract"-deployed by Delaware 's Court of Chancery to legitimate forum-selection bylaws-relies on an attenuated understanding of consent, and is singular even within contract law. Scrutinizing these bylaws from the standpoint of agency doctrine reveals the analytic and explanatory weakness of the "flexible contract." This Article examines potential amendments to the Delaware General Corporation Law that would ground consent more firmly and could cabin the scope and content of litigation-related bylaws. Absent such an amendment, shareholders are subject to the risk that, through a generic governance provision, directors may impose limitations on shareholders' rights that stem from sources external to the corporation itself, including generally applicable rules of civil procedure. Imposing this risk on shareholders charges them with notice of a fact not in existence at the time they invest and, more generally, serves to undermine a central mechanism of fiduciary accountability.

* David F. Cavers Professor of Law, Duke University School of Law. For comments and suggestions on an earlier draft, I thank Jim Cox, Andrew Gold, the Hon. Jack Jacobs, Mark Lebovich, Ann Lipton, and Stephen Radin. Thanks as well to the Institute for Law and Economic Policy for the opportunity to present my work at its 20th Annual Symposium on Business Litigation and Regulatory Agency Review in the Era of the Roberts Court. 


\section{TABLE OF CONTENTS}

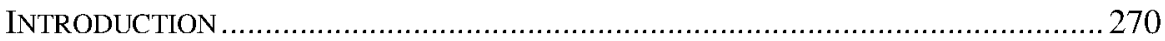

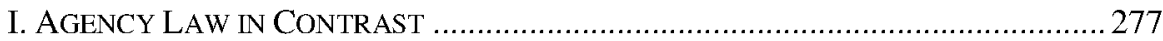

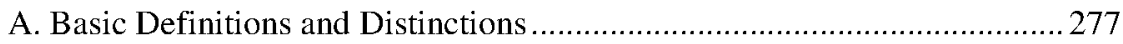

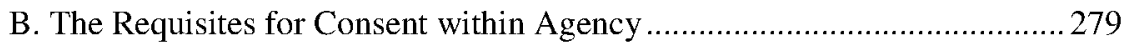

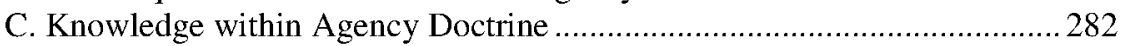

D. Parallels in Corporate Law Doctrine ......................................... 283

II. REVISITING THE ANALYSIS OF FORUM-SELECTION BYLAWS .......................286

A. Terminology and Concepts as Evolution Proceeds ........................ 286

1. Power, Authority, and Legitimacy ..................................... 286

2. Shareholders' Consent and Knowledge in Boilermakers ..................287

B. The Singularity of the "Flexible Contract".................................290

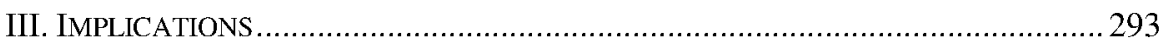

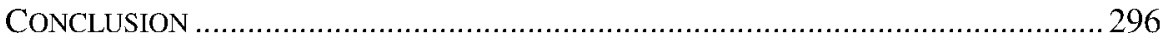

\section{INTRODUCTION}

A refractory object like a lens has the power to change the course of rays of light that pass through it, moving the rays out of their direct line and sometimes causing them to break up. This Article engages in a figurative refraction, examining forum-selection bylaws adopted through a board of directors' unilateral action from the standpoint of the common law of agency. To be sure, corporate law in the United States does not situate a corporation's directors as agents of its shareholders. Nonetheless, a compelling reason to entertain the perspective afforded by agency law is that it brings into clear focus issues that seem blurred in the debate surrounding director-adopted bylaws, which specify an exclusive forum for the litigation of claims falling within categories identified in the bylaws. In particular, consent is a carefully articulated concept within agency law, as are various forms of knowledge and notice. Using a precise vocabulary, agency doctrine delineates these concepts in a nuanced way that could enrich analysis of forum-selection bylaws. The extensive development of these concepts in agency doctrine stems from the underlying consequence of agency, which is that the agent becomes, for legal purposes, an extension of the principal's own self. Agency doctrine also delineates with precision the legal consequences of an agency relationship, ${ }^{1}$ which are not identical to those stemming from contract law, but many accounts of directors' bylaw powers presuppose the applicability of contract law.

This Article does not fully recount the history of bylaw and charter provisions that designate an exclusive forum for specified claims. In brief, proponents of forum-selection provisions characterize them as necessary responses to increases in litigation brought in jurisdictions other than where the target is

1. See generally RESTATEMENT (THIRD) OF AGENCY (2006). 
incorporated challenging merger-and-acquisition ("M\&A") transactions. ${ }^{2}$ A provision designating an exclusive forum may be present in a corporation's charter when it sells shares through an initial public offering ("IPO"); ${ }^{3}$ adding such a provision post-IPO requires majority approval from the then-outstanding shares. Separately, under the Delaware General Corporation Law ("DGCL"), the certificate of incorporation (the charter document), may confer on a corporation's directors the power-which would then run concurrently with power retained by shareholders- to adopt, amend, or repeal bylaws. ${ }^{4}$ Adding a forum-selection provision to M\&A deal documents binds only the parties to the transaction, not shareholders. ${ }^{5}$

In 2013, in Boilermakers Local 154 Retirement Fund v. Chevron Corp., ${ }^{6}$ the Delaware Court of Chancery upheld the statutory validity of forum-selection

2. On the dynamics of multijurisdictional litigation, see Leo E. Strine, Jr. et al., Putting Stockholders First, Not the First-Filed Complaint, 69 Bus. LAW. 1 (2013). For a more skeptical account of the costs imposed by multiforum litigation, see Randall $\mathrm{S}$. Thomas \& Robert B. Thompson, A Theory of Representative Shareholder Suits and Its Application to Multijurisdictional Litigation, 106 Nw. U. L. REV. 1753, 1801 (2012). More broadly, the relationship between deal litigation and outcomes is also significant. On the 1993-2001 merger boom, see C.N.V. Krishnan et al., Shareholder litigation in mergers and acquisitions, 18 J. Corp. Fin. 1248, 1250 (2012) (finding shareholder litigation to be "an important monitor of target shareholder value" even controlling for many factors including different standards applicable to different types of M\&A transactions).

3. The provision does not become effective until the corporation's restated certificate of incorporation is filed with Delaware's Secretary of State. See In re Facebook, Inc., IPO Sec. \& Derivative Litig., 922 F. Supp. 2d 445, 463 (S.D.N.Y. 2013) (under Del. Code Ann. tit. 8, § 103(d), plaintiffs were not bound by forum-selection clause in restated certificate of incorporation filed four days after IPO through which plaintiffs acquired their shares).

4. Del. Code Ann. tit. 8, § 109(a) (2014).

5. OTK Assocs., L.L.C. v. Friedman, 85 A.3d 696, 719-21 (Del. Ch. 2014) (holding that forum-selection clause in documents effecting recapitalization of Delaware corporation-which specified New York as exclusive forum for "[a]ll actions and proceedings arising out of or relating to this Agreement" — did not apply to shareholder suit alleging breach of fiduciary duty when "it has not traditionally been thought that a contractual forum selection provision in the transaction agreement governed the stockholder plaintiffs' claims for breach of fiduciary duty and aiding and abetting"). Otherwise, the court continued, "the solution to the problem of multi-forum litigation has been hiding in plain sight for decades, under the noses of the courts and corporate bar." Id. at 721 .

6. 73 A.3d 934, 958 (Del. Ch. 2013). Reactions to date from non-Delaware courts to forum-selection bylaws have been mixed. Compare Galaviz v. Berg, 763 F. Supp. 2d 1170, 1174 (N.D. Cal. 2011) (declining to dismiss derivative suit on basis of forumselection bylaw unilaterally adopted by corporation's directors after occurrence of wrongdoing from which claims alleged in suit stemmed; court unpersuaded that bylaws "are like any other contract... while simultaneously arguing that it was permitted under corporate law to amend those bylaws in a manner that it could not have achieved under contract law"), with Hemg, Inc. v. Aspen Univ., No. 650457/13, 2013 WL 5958388 (N.Y. Sup. Ct. Nov. 4, 2013) (relying on Boilermakers, the court dismissed plaintiff's derivative claims when the bylaw unilaterally adopted by corporation's directors specified Delaware forum as exclusive). For further discussion of Galaviz, see infra text accompanying notes 95-98. Recent commentary from practitioners counsels caution. See Paul Scrivano \& Noah 
bylaws adopted unilaterally by directors. ${ }^{7}$ The court held that directors had power to act unilaterally, and that the designation of an exclusive forum was within the scope of a bylaw's permissible content; the DGCL defines this in general terms as "any provision, not inconsistent with law or with the certificate of incorporation, relating to the business of the corporation, the conduct of its affairs, and its rights or powers or the rights or powers of its stockholders, directors, officers or employees." The bylaws at issue in Boilermakers covered: derivative suits brought on behalf of the corporation; nonderivative actions asserting claims of breach of fiduciary duty owed by any director, officer, or employee; claims arising under the DGCL; and any action "asserting a claim governed by the internal affairs doctrine." Each bylaw explicitly deemed any person "purchasing or otherwise

Kornblith, Exclusive Forum Bylaws: Further Consideration Recommended, O'MELVENY \& MYERS LLP, Mar. 17, 2014, available at http://www.omm.com/exclusive-forum-bylawsfurther-consideration-recommended-03-11-2014/ (noting risk of becoming "the next "test case" before a non-Delaware court and "by trying to erect a defense against potential future litigation, a company may be creating the reality of an actual present litigation."). Additionally, given that proxy advisory services take "a dim view" of forum-selection bylaws adopted unilaterally by directors, "generally public companies have gained little by taking actions that proxy advisory services disfavor." $I d$.

7. The relevant statutory provision is DEL. CODE ANN. tit. 8, § 109(a), which provides that after a corporation receives any payment for its stock, "the power to adopt, amend or repeal bylaws shall be in the stockholders entitled to vote ...." The corporation's certificate of incorporation may confer bylaw power on the corporation's directors, but "[t]he fact that such power has been so conferred upon the directors . . shall not divest the stockholders or members of the power, nor limit their power to adopt, amend or repeal bylaws." Id. To exercise bylaw power, shareholders must have a legally-salient occasion for shareholder action, in the case of a Delaware corporation either a shareholder meeting or written consent to adopting, amending, or repealing the particular bylaw or bylaws. See infra note 32 and text accompanying note 103. The Delaware General Corporation Law does not insulate shareholder-adopted bylaws against later-conflicting exercises of bylaw power taken by directors, nor does the statute provide a mechanism for shareholders to selfinsulate any bylaw they adopt or amend.

8. Del. CoDE ANN. tit. 8, $\$ 109$ (b). In a pre-Boilermakers opinion, the Court of Chancery noted that "boards of directors and stockholders" that believed a single forum to be advantageous for intra-corporate disputes "are free to respond with charter provisions selecting an exclusive forum ...." In re Revlon, Inc. S'holders Litig., 990 A.2d 940, 960 (Del. Ch. 2010).

9. 73 A.3d at 942. Boilermakers explicitly notes that a forum-selection bylaw could not apply to a stockholder "who sought to bring a tort claim against the company based on a personal injury she suffered that occurred on the company's premises" because the bylaw "would not deal with the rights and powers of the plaintiff-stockholder as a stockholder." Id. at 952. Tantalizingly, the opinion does not address whether such a bylaw could validly encompass fraud claims asserted by shareholders against the corporation, its fiduciaries, and their advisors and transactional intermediaries. Also not addressed are claims that are hard to characterize within categories included in, and excluded from, bylaws like those in Boilermakers. See, e.g., Friese v. Super. Ct., 134 Cal. App. 4th 693, 709-10 (2006) (claim brought by trustee as successor in interest against Delaware corporation's former directors and officers alleging insider trading claims arising under state statute, CAL. SEC. L. $§ 25000$ et seq., are not governed by internal affairs doctrine because they stem from state's interest in integrity of markets for securities within the state and 
acquiring" any interest in stock to have notice of, and to consent to, the bylaw. ${ }^{10}$ As drafted, the bylaws at issue in Boilermakers reached well beyond shareholder lawsuits filed in the wake of M\&A and other fundamental transactions. Finally, Boilermakers recognized the potential applicability of long-standing equitable doctrines that permit shareholders to challenge the adoption of bylaws on a caseby-case, situation-specific basis. ${ }^{11}$

Edgen Group Inc. v. Genoud, a post-Boilermakers bench ruling from the Court of Chancery, underlines the point of the exercise conducted in this Article. There, a target corporation sought an antisuit injunction directed at a shareholder who sued in a Louisiana state court challenging a proposed merger, despite the Delaware forum-selection provision in the corporation's charter. ${ }^{12}$ Nonetheless, the Edgen court denied the injunction, reasoning that, in balancing the equities, it was unconvinced that an antisuit injunction should be "the initial tool of judicial first resort," 13 as opposed to awaiting the Louisiana court's response to the defendant's motion to dismiss. ${ }^{14}$ In particular, the Court of Chancery identified personal jurisdiction as a potential stumbling block given that "simply owning stock in a Delaware corporation is not sufficient to confer personal jurisdiction on a Delaware court." 15 Additionally, the court emphasized that there was nothing in the certificate provision that addressed personal jurisdiction over shareholders. ${ }^{16}$

implicate broader interests than those of a corporation's shareholders). On the internal affairs doctrine, see infra text accompanying note 127.

10. Boilermakers, 73 A.3d at 942 .

11. Id. at 949 .

12. Transcript of Oral Ruling at 8-9, Edgen Grp. Inc. v. Genoud, No. 9055-VCL, 2013 WL 6409517 (Del. Ch. Nov. 5, 2013).

13. Id. at 43,46 .

14. Plaintiff in the Louisiana case, a Canadian resident, had not been susceptible to service of process in the Delaware suit. Accordingly, the Louisiana court granted the motion to dismiss on forum non conveniens grounds and did not issue a written opinion. See Genoud v. Edgen Grp., No. 625244, 2014 WL 2782221 (La. Dist. Ct. Jan. 17, 2014) (discussed in Joel C. Haims \& James J. Beha II, Commercial Division Enforces ForumSelection Bylaw, N.Y.L.J., Feb. 19, 2014, at 4, available at http://documents.jdsupra.com/a8bf45b0-5479-407a-aeee-2d90fb75be85.pdf). Another potential response is to obtain a default judgment in Delaware against the shareholder who sued elsewhere. See Nat'l Inv. Grp. (Holding) v. Carlyle Inv. Mgmt. L.L.C., 67 A.3d 373, 375-76 (Del. 2013).

15. Edgen, $2013 \mathrm{WL} 6409517$ at $* 34-35$.

16. $I d$. at 35 . In contrast, the certificate provision expressly addressed personal jurisdiction over indispensable parties named as defendants by conditioning the provision's applicability on the Court of Chancery's personal jurisdiction over indispensable defendants. $I d$. at 31,35 . The foundational authority for the insufficiency of stock ownership as a basis for personal jurisdiction when the controversy does not concern the stock itself is Shaffer $v$. Heitner, which invalidated Delaware's in rem sequestration process as inconsistent with the Due Process Clause as a mechanism for obtaining personal jurisdiction over nonresident officers and directors. 433 U.S. 186 (1977). As the Edgen court notes, in Delaware cases holding that negotiated contracts required the issuance of antisuit injunctions to enforce forum-selection provisions, the contracts contained language explicitly addressing personal jurisdiction over parties to the contract, not just indispensable defendants. See Nat'l Inv. Grp. (Holding), 67 A.3d at 377; ASDC Holdings L.L.C. v. Richard Malouf 2008 All Smiles Retained Grantor Annuity Trust, No. 6562-VCP, 2011 WL 
Further, the court characterized the status of forum-selection provisions as "an evolving issue." 17 The court differentiated forum-selection provisions contained in "negotiated agreements" from those governing disputes involving "non-direct signatories." 18 The latter category encompasses the connection between shareholders in a corporation and either forum-selection certificate provisions (as in Edgen), or the consequences of the bylaw power conferred on directors (as in Boilermakers).

Focusing on agency doctrine makes clear that corporate shareholders who are subject to a forum-selection bylaw unilaterally adopted by directors are even more unlike the parties to a negotiated agreement than was the shareholder in Edgen. This is because shareholders are linked to a forum-selection provision only by the downstream consequences of a generic governance provision conferring bylaw power on directors - as opposed to an explicit provision present in the corporation's certificate of incorporation at the time of the IPO. This link is too attenuated to satisfy the requisites for consent and knowledge articulated in agency-law doctrine. Nonetheless, similar to the principal-agent relationship, Boilermakers empowers corporate boards to take action with direct legal consequences for shareholders-actions bearing on rights not entirely originating with the corporation itself, including the applicability of general rules of civil procedure which specify permissible venues. The court's analysis in Boilermakers relies on attenuated concepts of consent and notice. These concepts become operative once an investor acquires shares in a Delaware corporation with a certificate provision conferring bylaw power on directors, through which the investor as shareholder becomes a party to a "flexible contract" with the corporation acting through its directors. ${ }^{19}$

4552508 at $* 6$ (Del. Ch. Sept. 14, 2011). See also Capital Grp. Cos. v. Armour, No. Civ. A. 422-N, 2004 WL 2521295 (Del. Ch. Oct. 29, 2004) (trustee bound by consent-tojurisdiction clause in contract restricting transfer of stock owned by trust). For further discussion of Shaffer, see infra text accompanying notes 22 and 130-134.

17. Edgen, 2013 WL 6409517 at *42. To the court, it was "not at all clear... that forum selection provisions are as yet sufficiently understood and accepted such that" the Delaware Supreme Court would mandate that provisions in corporate charters and bylaws be treated identically to provisions contained in negotiated agreements, at least when the question, as in Edgen, is whether the court should enforce a forum-selection provision by issuing an injunction against maintaining a suit filed elsewhere. Id. at *43.

18. Id. at $* 42-44$

19. Boilermakers Local 154 Retirement Fund v. Chevron Corp., 73 A.3d 934, 939 (Del. Ch. 2013) ("[T]he bylaws of a Delaware corporation constitute part of a binding broader contract among the directors, officers, and stockholders formed within the statutory framework of the DGCL. This contract is, by design, flexible and subject to change in the manner that the DGCL spells out and that investors know about when they purchase stock in a Delaware corporation." (citation omitted)). Neither of the two cases cited by the court involves a bylaw that is formally or substantively similar to the Boilermakers bylaws, but in both cases the Delaware Supreme Court characterizes bylaws as contractual. See Airgas, Inc. v. Air Prods. \& Chems., Inc., 8 A.3d 1182, 1188-89 (Del. 2010) (invalidating bylaw proposed by shareholders that would have accelerated date of annual meeting); Lawson v. Household Fin. Corp., 152 A. 723, 726 (Del. 1930) (appellant bound by restriction on share 
As this Article demonstrates, the "flexible contract" and its operation are singular even when considered side-by-side with the boilerplate quality of many consumer contracts-including those containing terms imposed through a process of "rolling contract formation." ${ }^{20}$ Additionally, nothing in the DGCL or any other Delaware statute explicitly alerts investors to possible downstream impediments on their right to sue in compliance with applicable rules of civil procedure, including choice of forum. ${ }^{21}$ In contrast, a director or officer of a Delaware corporation impliedly consents to the corporation's registered agent as that person's agent for purposes of service of process, an implied consent grounded in an explicit statutory provision. ${ }^{22}$ Additionally, unlike the statutory limits on certificate provisions limiting director liability, the DGCL does not regulate the content of forum-choice bylaws. ${ }^{23}$ Perhaps unsurprisingly, the prospect that bylaws might serve as vehicles to impose provisions mandating arbitration (and waiving the right to proceed as a class in shareholder suits), shift fees and costs to plaintiffs ultimately not "successful" as defined in the bylaws, or deem share ownership as consent to personal jurisdiction in Delaware, has not gone unnoticed. ${ }^{24}$

transfer present in corporation's charter and bylaws when appellant's vendor acquired shares).

20. See, e.g., John E. Murray, Jr., The Dubious Status of the Rolling Contract Formation Theory, 50 DUQ. L. REv. 35, 36 (2012) (noting that majority of jurisdictions have yet to address theory). For further discussion of contracts formed through a rolling process, see infra text accompanying notes 86-88 and 111-112.

21. See Thomas \& Thompson, supra note 2, at 1972 (characterizing a plaintiff's right to choose where to file suit among multiple forums that are permissible as a "fact [of] the rules of civil procedure," and observing that plaintiffs' choices of among particular forums "does not mean that they are cheating in the litigation 'chess game' so long as they are playing within the procedural and substantive rules").

22. DEL. CODE ANN. tit. 10, \$3114(a)-(b) (2014). The consent-to-service provision was added as a response to Shaffer v. Heitner, discussed supra note 16 and infra text accompanying notes $130-134$.

23. DEL. CODE ANN. tit. $8, \S 102($ b)(7), added to the Delaware statute to facilitate the availability of director and officer liability insurance, does not permit exculpation against the liability of a director that stems from a breach of the duty of loyalty, an action not in good faith, an action from which the director obtained an improper personal benefit, or from illegally paying a dividend or making a share repurchase or redemption. See R. Franklin Balotti \& Mark J. Gentile, Elimination or Limitation of Director Liability for Delaware Corporations, 12 DEL. J. CORP. L. 5, 11 (1987). DEL. CODE ANN. tit. 8, $\S 102(b)(7)$ is limited to directors and to monetary liability. Id. In the absence of an enabling provision in the relevant corporation statute, the validity of exculpation provisions is not clear, and provisions that created a "substantial possibility of fraud or overreaching are likely invalid." See Principles of CORPORATE Governance: ANALYsis AND RECOMMENDATIONS $§ 7.19$, cmt. d (1994). For further discussion of statutory provisions that enable the adoption of exculpatory provisions, see infra text accompanying notes 136-138.

24. On arbitration bylaws, see Claudia H. Allen, Bylaws Mandating Arbitration of Stockholder Disputes, 39 DEL. J. CORP. L. (forthcoming 2015). On fee-shifting bylaws, see ATP Tour, Inc. v. Deutscher Tennis Bund, 91 A.3d 554, 558 (Del. 2014) (answering certified question and upholding statutory validity of fee-shifting bylaw in nonstock corporation). See also William Savitt, Ruling on Fee-Shifting Bylaws Raises Hackles, NAT'L L. J., June 2, 2014, at 10 (noting that a board's decision to adopt a fee-shifting bylaw in the public-company context implicates "an inherent tension between the legitimate corporate 
As it happens, an earlier attempt to implement a contractualized vision of entity governance through Delaware law recently occasioned a deeply disillusioned account from two prominent Delaware judges, the now-former Chancellor (the present Chief Justice of the Delaware Supreme Court) and an incumbent Vice-Chancellor. Then-Chancellor Strine and Vice-Chancellor Laster adjudicated many cases involving noncorporate entities-limited partnerships and limited liability companies-whose organizers varied or eliminated fiduciary duties of loyalty for entity managers, as Delaware law permits. Far from invoking images of arms-length bargaining, Leo Strine and Travis Laster recount entitygovernance terms dictated by entity sponsors with adverse effects aggravated by the lack of standardization, all the while with no realistic opportunity for prospective investors to negotiate these terms. ${ }^{25}$ The reality, in other words, is not bargained-for governance terms but manager-favorable terms imposed on a take-itor-leave it basis. ${ }^{26}$ To be sure, the alternate-entity context differs from the corporate context on which this Article focuses. Nonetheless, the authors' cautionary insights carry general implications; the most fundamental is that characterizing a term as part of a "contract" does not mean that the term resulted from bargaining or that it will be optimal in application.

This Article opens in Part I with a brief outline of the agency doctrine and, in particular, how agency defines the concepts of consent, knowledge, and notice. As it happens, these definitions have intriguing parallels in corporate-law doctrines. Those parallels can be used to defeat arguments that shareholders should be understood to have consented to unspecified future conduct that was unknowable at the time of the purported consent. Following this excursion through agency doctrine, Part II revisits the analysis of forum-choice bylaws, noting the ambiguities in terminology used in the Boilermakers opinion, and then explains why the "flexible contract" is indeed a singular and dissonant instance from the perspective of contemporary contract law. Part III concludes with implications of the analysis and argues that the "flexible contract" is too weak to bear the weight assigned it. Amendments to the DGCL are warranted to overcome the thinness of consent and notice associated with the "flexible contract" and to cabin the bylaw power as an instrument for undermining fiduciary accountability.

goal of deterring litigation and the danger of self-interested director action."). The feeshifting controversy accelerated, leading to a (yet-unenacted) proposed statutory amendment limiting the import of ATP to nonstock corporations. Id.; see also Lawrence A. Hamermesh, Consent in Corporate Law, 70 Bus. LAw. 161, 168 (2014) (examining potential limits that legislation might impose on actions directors may take through unilateral action in light of questions "about the meaningfulness of consent").

25. See Leo E. Strine, Jr. \& J. Travis Laster, The Siren Song of Unlimited Contractual Freedom, in RESEARCH HANDBOOK ON PARTNERSHIPS, LLCS, AND ALTERNATE FoRMS OF Business ORGANIZATIONS (Robert W. Hillman \& Mark J. Loewenstein eds., forthcoming 2015), available at http://ssm.com/abstract=2481039. Strine and Laster's critique identifies poor drafting and lack of clarity as factors that complicate the interpretation of entity-specific terms that purport to eliminate or reformulate the duties owed by alternate-entity managers and lead to judicial decisions of little precedential value.

26. In contrast, the alternate-entity world has often been assumed to be one characterized by investors who are "capable of negotiating and appreciating the consequences of their decisions ...." See, e.g., Hamermesh, supra note 24. 


\section{Agency Law in Contrast}

\section{A. Basic Definitions and Distinctions}

As defined by the common law, agency is a "fiduciary relationship that arises when one person (a 'principal') manifests assent to another person (an 'agent') that the agent shall act on the principal's behalf and subject to the principal's control, and the agent manifests assent or otherwise consents so to act." ${ }^{27}$ When a relationship fits within the common law definition, the principal becomes a party to transactions entered into by the agent within the scope of the agent's actual or apparent authority, and noncontractual liabilities incurred by the agent acting within those bounds likely extend to the principal as well. Assets that the agent acquires on the principal's behalf become vulnerable to claims asserted by the principal's creditors. Forming a corporation has long sidestepped these basic consequences of common law agency for investors in the corporation's equity. ${ }^{28}$

Additionally, and more importantly for purposes of this Article, the definition of common law agency requires that a principal have the right to control the agent. This includes the power to furnish instructions to the agent on an interim basis, even when the principal has previously agreed that the agent may exercise discretion within the scope of the agent's authority. ${ }^{29}$ Thus, an actor is not an agent when that actor is not subject to interim control by another person who has the power to exercise it. ${ }^{30}$ On this criterion, corporate law does not position shareholders and directors in an agency relationship. Once having elected directors, shareholders lack ongoing power to furnish binding instructions comparable to the basic power of a principal in a relationship of common law agency. ${ }^{31}$ Moreover, once having elected a director, the shareholders' power to remove the director from office is subject to the applicable corporation statute. ${ }^{32}$ In

27. RestateMEnT (THIRD) OF AGENCY $§ 1.01$ (2006).

28. For further elaboration of these points, see Deborah A. DeMott, Shareholders as Principals, in Key Developments IN CoRPORATE LAW and Trusts Law: EsSAYs IN HONOUR OF PROFESSOR HAROLd FORD 105 (Ian Ramsay ed., 2001).

29. Restatement (THIRD) OF AGENCY $\$ 1.01, \mathrm{cmt}$. f(1).

30. For a recent application, see Hollingsworth v. Perry, 133 S. Ct. 2652, 266667 (2013) (proponents of ballot initiative to amend state constitution lacked standing to defend its constitutionality in federal court when elected state officials declined to defend initiative; proponents, who "answer[ed] to no one," and owed no fiduciary duty to citizens of state, were not agents of state or its citizens).

31. RestATEMENT (THIRD) OF AGENCY $\$ 1.01 \mathrm{cmt}$. $\mathrm{f}(2)$. In a much earlier era of corporate law, directors were subject to shareholders' power to give binding instructions. See DeMott, supra note 28, at 108.

32. DeMott, supra note 28, at 108 . Under the DGCL, directors may be removed, with or without cause, by "the holders of a majority of the shares then entitled to vote at an election of directors ...." DEL. CODE ANN. tit. 8, \& 141(k) (2014). Highly significant statutory exclusions constrain this power, chief among them the consequences of a classified board. If the board is classified-its directors stand for election in groups of overlapping classes-then unless the corporation's certificate provides otherwise, directors may be removed only for cause. $I d . \S 141(\mathrm{k})(1)$. In recent years, staggered boards have been in decline due to shareholder pressure, to which directors acquiesced. See Edward B. Rock, 
contrast, under common law agency, a principal has the power to reduce the agent's authority, as well as to terminate the principal-agent relationship-a power the principal may exercise even when doing so would breach a contract previously made with the agent. ${ }^{33}$ Therefore, formally situating the relationship between shareholders and directors outside the ambit of common law agency enhances the stability and continuity of directors' positions.

Although these features differentiate the shareholder-director relationship from common law agency, agency law provides a foundation for understanding the law applicable to business organizations, including corporations. ${ }^{34}$ Moreover, well regarded judicial opinions and academic commentary seem drawn to using agencylaw terminology in discussing the shareholder-director relationship. ${ }^{35}$ Like principals who consent to representation by an agent, shareholders vote to elect their corporation's directors. Additionally, in exercising board discretion, directors act as fiduciaries on behalf of the corporation for the benefit of shareholders as a group. These fundamental structural similarities appear to exert gravitational pull of at least a rhetorical sort and, as this Article argues, make the substance of agency law relevant for more than rhetorical flourishes. A sketch of agency doctrines relevant to consent and knowledge follows next.

Adapting to the New Shareholder-Centric Reality, 161 U. PA. L. REV. 1907, 1924-25 (2013). The DGCL permits shareholders to take action at a shareholder meeting or through written consent given by the number of shares requisite to the particular action. See DEL. CODE ANN. tit. $8, \S 228$ (a). However, a corporation's certificate may exclude the written consent procedure, see $i d$., with the consequence that a meeting would be the sole occasion for shareholder action, including the removal of directors. Under the DGCL, the power to call a shareholder meeting is a power of the board, subject to provisions contained in the corporation's certificate of incorporation or bylaws. DEL. CODE ANN. tit. 8, §211(a). There's no counterpart to the statutory power to call a special meeting that the Revised Model Business Corporation confers on shareholders, exercisable through a written demand subscribed by at least $10 \%$ of the votes entitled to be cast on any issue proposed for the meeting. See REv. Model Bus. CORP. ACT $\S 7.02(a)(2)$ (2010). Although under the Model Act action by shareholders without a meeting requires unanimous support "by all the shareholders entitled to vote on the action," id. $\S 7.04(\mathrm{a})$, the corporation's articles may provide for action by less-than-unanimous support, comparable to the Delaware provision, id. $\$ 7.04$ (b). Overall, the DGCL provides more mechanisms to constrain shareholders' power to act because a certificate provision may eliminate the power to take action through written consent, while shareholders' power under the Model Act to call a special meeting is a mandatory power not subject to provisions eliminating it in a corporation's articles.

33. RESTATEMENT (THIRD) OF AGENCY $\$ 3.10$.

34. See Eric W. Orts, Business Persons: A Legal Theory of the Firm 54 (2013) (commenting that "[f]irms of any complexity beyond a single individual cannot exist without the law of agency ... agency law provides an essential foundation for the legal structure of modern firms.").

35. E.g., Blasius Indus., Inc. v. Atlas Corp., 564 A.2d 651, 659-60 (Del. Ch. 1988) (" $[\mathrm{A}]$ decision by the board to act for the primary purpose of preventing the effectiveness of a shareholder vote inevitably involves the question who, as between the principal and the agent, has authority with respect to a matter of internal corporate governance."); Credit Lyonnais Bank Nederland, N.V. v. Pathe Commc'ns Corp., No. 12150, 1991 WL 277613, at*34 (Del. Ch. Dec. 30, 1991) ("At least where a corporation is operating in the vicinity of insolvency, a board of directors is not merely the agent of the residue risk bearers, but owes its duty to the corporate enterprise."). 


\section{B. The Requisites for Consent within Agency}

The court's reasoning in Boilermakers is premised on implied consent, given when an investor acquires equity in a corporation. Within many legal fields, consent has been characterized as an "essentially contested concept" that lacks a generally accepted meaning, but also is open to respectable arguments over what meaning is preferable in a particular context. ${ }^{36}$ Scholars often lament the conceptual muddles that surround consent. ${ }^{37}$ For example, focusing on the law of torts, Kenneth Simons acknowledges that "the term 'consent' is notoriously ambiguous." 38 In criminal law, a rich literature disputes how consent should be defined and understood. ${ }^{39}$ In contract law, although the pervasiveness of the concept and rhetoric of consent are widely acknowledged, consent's elusiveness and its occasional tenuity are the focus of scholarly inquiry, ${ }^{40}$ as discussed later in this Section. In contrast, within agency law, although consent-related doctrines are complicated, their import is relatively clear and settled, and their underlying

36. W.B. Gallie, Essentially Contested Concepts, 56 Proc. ARISTOTELIAN Soc'Y 167, 169 (1956) (quoted in David Horton, Mass Arbitration and Democratic Legitimacy, 85 U. COLO. L. REV. 459, 480 (2014)). Gallie's paper associated essentially contested concepts with "appraisive concepts," implied by the statement that "[t]his picture is a work of art" but not by the statement that "[ $[\mathrm{t}]$ his picture is painted in oils." Id. at 167 . But rational discussion can occur over the justifications for preferring one definition of "work of art" over another. More generally, "to use an essentially contested concept means to use it against other uses and to recognize that one's own use of it has to be maintained against these other uses." Id. at 173.

37. The meaning of "consent" in corporate law has been explored less extensively than in other fields. One focal point for scholarly engagement is corporate law's majoritarian stance. See Faith Stevelman, Regulatory Competition, Choice of Forum, and Delaware's Stake in Corporate Law, 34 DEL. J. CoRP. L. 57, 132 (2009) (shareholderenacted bylaws restricting forum choice "are 'consensual,' as consent is defined in corporate law (i.e., where a vote of the majority shares is binding on the rest)"); Randall S. Thomas, What Should We Do About Multijurisdictional Litigation in M\&A Deals?, 66 VAND. L. REV. 1925, 1955 (2013) (noting collective action and strategic-choice problems for shareholders in voting on provisions). For a recent examination of potential limits on consent-based theories in the wake of Boilermakers, see Hamermesh, supra note 24. Consent in corporate law is discussed further in Part III.

38. See Kenneth W. Simons, Exploring the Relationship between Consent, Assumption of Risk, and Victim Negligence, in PHILOSOPHICAL Foundations OF THE LAW OF TORTS 272, 274 (John Oberdiek ed., 2014). Professor Simons distinguishes "the minimal concept of assent, which is, ... roughly, a preference or willingness that the conduct occur" from "the more robust concept of legally binding consent ... which is assent given with sufficient levels of knowledge, competence, and freedom of choice." Id.

39. For examples within this literature, see PETER WESTEN, THE LOGIC OF Consent: The Diversity and DeCEPTIVEness of Consent as a DeFENSE to CRIMINAL Conduct (2004); Larry Alexander, The Ontology of Consent, 55 AnAlytic PhIL. 102 (2014). On the differentiation drawn by criminal law between instances of prospective and retrospective consent, see Jonathan Witmer-Rich, It's Good to be Autonomous: Prospective Consent, Retrospective Consent, and the Foundation of Consent in the Criminal Law, 5 CRIM. L. \& PHIL. 377 (2011).

40. See, e.g., Chunlin Leonhard, The Unbearable Lightness of Consent in Contract Law, 63 CASE W. RES. L. REV. 57 (2012); Margaret Jane Radin, Humans, Computers, and Binding Commitment, 75 IND. L.J. 1125 (2000). 
rationale is coherent. The requisites for legally effective consent vary within agency doctrine, resulting in a nuanced set of concepts and terminology. In general, in order to specify when a principal has effectively consented to an agent's conduct, agency doctrine differentiates between two situations. In the first, the question is whether the principal's present knowledge and preferences should be determinative; in the second, the question is whether the principal's more generalized (or earlier) expressions of assent should bind the principal to the legal consequences of the agent's conduct. Additionally, "assent" is a broader term in agency doctrine, while consent is narrower and more demanding. ${ }^{41}$

Consider first how agency doctrine articulates the underpinnings of consent in forming an agency relationship. As noted above, the formal definition of the relationship requires that the principal "manifest[] assent" to representation by the agent, subject to the principal's control. ${ }^{42}$ Agency is unquestionably a consensual relationship, but the terminology for its inception on the principal's side is "assent," not "consent." 43 By requiring only "assent," agency law does not shelter principals who claim to harbor unexpressed reservations or limitations that were not earlier shared with the agent. ${ }^{44}$ Additionally, although implicitly assenting to an agent's representation also specifies the scope of the agent's actual authority to represent the principal, it is not required that the principal foresee and specify, at the outset of the agency relationship, all that the agent might do within the scope of the agent's authority. And an agent might, as the formal definition acknowledges, become a party to an agency relationship by either assenting to the principal's manifestation, or "otherwise consent[ing]" to the relationship. An agent might simply perform the service that the principal requested, and, knowing that the principal so requested, the agent has consented to forming the relationship. ${ }^{45}$

A conceptual challenge for accounts of agency doctrine is explaining how a principal might be said to consent or assent to becoming a party to a contract with a third party ${ }^{46}$ through subsequent transactions entered into by the agent when, although the agent acted within the scope of actual authority, the principal did not separately and contemporaneously agree to be bound by the specific contract. The solution embodied within agency doctrine can be understood as a form of consent that "exists in the 'background" during the agent's negotiations ${ }^{47}$-or, more vividly, as "lurking" consent that springs into contractual effect when the agent acts within the scope of actual authority. To the same

\footnotetext{
41. Restatement (ThiRd) of AGEnCy $\$ 1.01$, cmt. d (2006) (differentiating "consent" from "assent")

42. Id. $\S 1.01$.

43. Id. $\S 1.01$, cmt. d.

44. Id.

45. Id.

46. In general, forming a contract "requires a bargain in which there is a manifestation of mutual assent to the exchange and a consideration." RESTATEMENT (SECOND) OF CONTRACTS $\$ 17(1)$ (1981). A bargain is "an agreement to exchange promises or to exchange a promise for a performance or to exchange performances." Id. $\S 3$. An "agreement" requires a "manifestation of mutual assent." $I d$.

47. See Danny Busch \& Laura J. Macgregor, Introduction, in THE UNAUTHORISED AGENT 1, 2 (Danny Busch \& Laura J. Macgregor eds., 2009).
} 
practical end but deploying similes drawn from natural science, the Scots institutional writer G.J. Bell wrote in the nineteenth century that mandate-the civilian equivalent of agency-either "operates by an incessant renewal of the consent which confers the authority, like the operation of gravity on a descending body" or that the principal's initial expression operates "like an impulse on a natural body, the motion from which continues after having been once communicated." 48 Separately, these accounts of assent also accommodate the robust doctrine of apparent authority, which holds principals accountable for the consequences of reasonable beliefs held by third parties about the presence and scope of actual authority when the belief is traceable to a manifestation of the principal. $^{49}$ The principal's earlier manifestation remains operative or "lurking," so long as it remains reasonable for a third party to believe that the agent or other actor in question has authority to act on behalf of the principal. ${ }^{50}$

However, initial assent by the principal that creates actual or apparent authority-which need not fully specify the transactions or other conduct to which the principal consents-may prove inadequate when the question is whether the principal has consented to action by the agent that would, absent consent, breach the agent's duty of loyalty to the principal. Consent in this context requires that the agent acted in good faith in obtaining the principal's consent, and that the principal knew the material facts about the agent's conduct (either for a particular act or transaction, or for acts or transactions specified by type that could reasonably be expected to occur in the ordinary course of the agency relationship). ${ }^{51}$ Thus, in Rural Metro Corp. Stockholders Litigation, the court found ineffective language in an engagement letter through which the board of a target company purportedly consented to its financial advisor's conflicts; unbeknownst to the target's board, the advisor planned to seek an additional role, that of furnishing buyer-side

48. G. J. Bell, I COMMEnTARIES ON THE LAW OF SCOTLAND AND ON THE PrinCiPles of MERCANTILE JuRISPRUdenCE 522-23 (J. McLaren ed., 7th ed. 1870) (quoted in Laura J. Macgregor, The LaW of Agency in SCOTLAND 30 (2013)).

49. Formally defined, apparent authority is "the power held by an agent or other actor to affect a principal's legal relations with third parties when a third party reasonably believes the actor has authority to act on behalf of the principal and that belief is traceable to the principal's manifestations." RESTATEMENT (THIRD) OF AGENCY § 2.03. Apparent authority is a "power" because it is operative even when the agent lacks authority, i.e., actual authority, or is not an "agent" but an actor reasonably believed by the third party to be the principal's agent on the basis of a manifestation made by the principal. For a recent example, see Jones v. HealthSouth Treasure Valley Hosp., 206 P.3d 473 (Idaho 2009) (hospital subject to liability for torts of independent personnel who performed services when recipient of services reasonably believed, based on manifestations made by hospital, that services were being performed on its behalf). Although some scholars of other legal systems associate "authority" exclusively with "contractually based" authority, see MACGREGOR, supra note 48, at 31, agency doctrine in the United States recognizes that an agent may act with actual authority in committing a tort. See RestatemEnT (THIRD) OF AGENCY $\$ 7.04$.

50. RESTATEMENT (THIRD) OF AGENCY $\S 3.11(2)$.

51. $\quad I d . \S 8.06(1)$ 
financing to any acquirer. ${ }^{52}$ Characterizing the language as a "generalized acknowledgment" of the possibility of conflicts, the court held that it was inadequate to disclaim the client's reliance on the advisor. ${ }^{53}$ Moreover, to obtain such a waiver without first disclosing the conflict and its significance would constitute "what in the old days might have been called constructive fraud." 54 Rural Metro is consistent with ratification under agency doctrine because ratification by a principal of an agent's prior unauthorized act requires that the principal have knowledge of the material facts of the agent's unauthorized action. ${ }^{55}$

Whether the question is consent to an agent's disloyalty or ratification of unauthorized conduct, a principal's manifestation of consent is not effective unless it is specific and is given with knowledge of material facts. ${ }^{56}$ These requirements reflect the fundamental point that an agent is, on an ongoing basis, a legally salient extension of the principal. ${ }^{57}$ If a principal retains the power at any time to terminate its relationship with the agent, it is unsurprising that agency doctrine imposes more stringent requirements for consent when the agent's conduct exceeds the bounds initially drawn by the principal or contravenes the agent's fiduciary duty of loyalty to the principal. Thus, the concept of consent within agency doctrine is at odds with the implied consent that underlies the court's analysis in Boilermakers. Directors acting unilaterally in adopting forum-selection bylaws eliminate shareholders rights, and do so without any fresh or contemporaneous manifestation of assent from shareholders. Additionally, shareholders are not given prior notice of the impending change because, unlike an amendment to the corporation's certificate of incorporation, amending or adopting a new bylaw requires no filing with the state. ${ }^{58}$

\section{Knowledge within Agency Doctrine}

Agency doctrine also defines various forms of knowledge. To have "notice" of a fact encompasses situations that fall short of "knowing" that fact. ${ }^{59}$ As discussed in the preceding paragraph, if a principal has "knowledge" of a material fact, the principal knows the fact. On the other hand, if the principal has only "reason to know" the fact, the principal knows other facts from which "the

52. 88 A.3d 54, 100-01 (Del. Ch. 2014). The advisor urged that the language be treated as effective to exculpate it from liability for aiding and abetting breaches of fiduciary duty by the target's directors.

53. Id.

54. Id. at 101 (quoting Hollinger Int'1, Inc. v. Black, 844 A.2d 1022, 1068 (Del. Ch. 2004), aff'd, 872 A.2d 559 (Del. 2005)).

55. RestATEMENT (THIRD) OF AGENCY $\S \S 4.01,4.06$ (2006).

56. $\quad I d . \S \S 8.06(1)(\mathrm{a})(\mathrm{ii}) ; 4.06$.

57. See Deborah A. DeMott, The Fiduciary Character of Agency and the Interpretation of Instructions, in PHILOSOPHICAL Foundations OF FIDUCIARY LAW 321, 328-29 (Andrew S. Gold \& Paul B. Miller eds., 2014).

58. To be sure, in a public corporation the adoption of a forum-selection bylaw appears to be a current event of interest to shareholders to be reported on Form 8-K. See Form 8-K, U.S. SECS. \& ExCH. COMM'N, www.sec.gov/answers/form8k.htm (last visited Jan. 23, 2015) (Instructions for Form 8-K).

59. Restatement (ThIRD) OF AGEnCy $\$ 5.01(3) \& \mathrm{cmt}$. b. 
fact" at issue might reasonably be inferred ${ }^{60}$ Agency doctrine reserves "should know" situations for those in which one person has a duty to know a fact in order to fulfill a duty to another person. ${ }^{61}$

Key to the remainder of this Article is agency doctrine's recognition that an agent's knowledge, including of facts concerning the principal, may well exceed that of the principal. ${ }^{62}$ Thus, as noted above, a principal's affirmation of an otherwise-unauthorized act is effective to ratify it only when the principal knows the material facts at the time of the affirmation. ${ }^{63}$ Although the ratification doctrine does not impose a formal duty of disclosure on the agent, often the agent will be the most likely source of enlightenment. ${ }^{64}$ An agent's actual authority does not encompass actions in accord with customs or usages of a trade or locale when the agent has notice that the principal is unaware of them and the end result would be a transaction that differs from that which the agent has notice the principal wishes. ${ }^{65}$ More generally, an agent's duties of performance include using reasonable efforts to furnish material facts to the principal when the agent knows they are material to the agent's duties to the principal. ${ }^{66}$ The analysis in Boilermakers, in contrast, does not require that shareholders know that their board proposes to adopt a forumselection bylaw. At most, shareholders have reason to know that the board's bylaw powers are extensive —or shareholders' advisors may so inform them-and that, as time goes by, alert shareholders may come to realize with more detail just how that power could be used.

\section{Parallels in Corporate Law Doctrine}

Boilermakers aside, the basic distinctions drawn by common law agency are paralleled by some contemporary applications of corporate-law doctrine. One recent example is the Court of Chancery's analysis in Seinfeld $v$. Slager, a derivative suit brought by a shareholder that challenged, inter alia, awards of shares made by the corporation's directors to themselves under a stock incentive plan. ${ }^{67}$ Challenging the awards as a waste of corporate assets stemming from selfdealing by the board, the shareholder confronted the fact that the stock plan had been approved by the corporation's shareholders with terms that placed, in the court's characterization, "few, if any, bounds on the [b]oard's ability to set its own

60. Id. $\S 1.04(4)$.

61. Id. Nor is this concern for precision in the terminology associated with knowledge a recent development in agency doctrine. See, e.g., Warren A. Seavey, Notice Through an Agent, 65 U. PA. L. REv. 1 (1916).

62. Richard R.W. Brooks, Knowledge in Fiduciary Relations, in PHLOSOPHICAL Foundations of Fiduciary Law 225, 237-38 (Andrew S. Gold \& Paul B. Miller eds., 2014). Undoubtedly the need for precision stems from another basic consequence of an agency relationship that is beyond the scope of this Article: the imputation of the agent's knowledge to the principal, of course within bounds and subject to exceptions. RESTATEMENT (THIRD) OF AGENCY \& 5.03.

63. RESTATEMENT (THIRD) OF AGENCY $\$ 4.06$

64. Id. cmt. b.

65. $I d . \S 2.02 \mathrm{cmt}$. $\mathrm{e}$.

66. Id. $\$ 8.11$.

67. No. 6462-VCG, 2012 WL 2501105 (Del. Ch. June 29, 2012). 
stock awards." 68 Indeed, the plan conferred sole discretion on the board to make stock awards to its members, subject only to a total maximum limit under the plan of shares available for awards plus a per-awardee annual maximum. ${ }^{69}$ The court held that the plan's terms were insufficiently defined to insulate the board from the shareholder's self-dealing attack. The court reasoned that, although the shareholders had approved the plan and its explicit conferral of discretion on the board, "there must be some meaningful limit imposed by the stockholders on the [b]oard" to warrant treating the board's self-dealing as a legitimate exercise of its business judgment. ${ }^{70}$

To be sure, the context in Seinfeld differs in formal respects from a board's unilateral adoption of a forum-selection bylaw. As a consequence of their decisions as a board, the Seinfeld directors received direct pecuniary benefit that was not equivalently available to all shareholders. While directors may benefit by specifying an exclusive forum for shareholder-initiated litigation, the benefit is not so easily treated as a pecuniary benefit to individual directors. ${ }^{71}$ Additionally, the Seinfeld directors made the stock awards to themselves by using their administrative power, not by relying directly on the board's statutory power to issue stock. ${ }^{72}$ A board's exercise of its bylaw power more explicitly invokes statutory conferrals of power because it lacks any interim act of approval from shareholders. ${ }^{73}$ Despite these formal differences, it's striking that Seinfeld emphasizes the insufficiency of "a stockholder-approved carte blanche to the directors" via a plan that conferred "absolute discretion" on the board. ${ }^{74}$ Put differently, the court did not hypothesize that, in voting for the plan, the corporation's shareholders were sufficiently on notice of the possibility the board might make use of its conferred discretionary administrative power to make awards to itself such that, when one such use occurred, the shareholders should be deemed to have known of and consented to it. In Seinfeld, unlike a principal's initial manifestation of assent to an agent that gives its agent actual authority, the

68. Id. at $* 11$.

69. Id.

70. $I d$. at $* 12$. The board thus had the burden of proving that the self-awards were entirely fair, which is the standard of review under Delaware law applicable to selfdealing transactions not otherwise insulated from the standard.

71. This is especially so when the costs of a director's defense and any payments made in settlement are advanced and indemnified by the corporation or funded through insurance.

72. Under the DGCL, the board's powers include authorizing the issuance of stock for such consideration as the board shall determine, and the board's determination as to the value of the consideration is conclusive in the absence of actual fraud. See DEL. CODE ANN. tit. 8, $\S 152$ (2014). The stock plan in Seinfeld provided generally for administration by a committee of non-employee directors, or by the board itself if no such committee existed; for awards to non-employee directors, the plan deemed the board to be the committee. 2012 WL 2501105 at $* 10$.

73. Although theoretically, a corporation's conferral of bylaw power on directors could condition its exercise on obtaining specific approval from shareholders, DEL. CODE ANN. tit. 8, § 109 does not address the effectiveness of conditions imposed on directors' exercise of bylaw power.

74. Seinfeld, 2012 WL 2501105 at $* 10$. 
shareholder approval did not continue to "lurk" in the background to later spring into effectiveness when the board exercised its discretion to make self-awards. Instead, the Seinfeld court's analysis characterizes the context as one in which the directors-like an agent acting without authority or in breach of fiduciary dutymay not rely on an initial conferral of authority however broadly stated.

Common law agency's basic distinctions are also consistent with the Delaware Supreme Court's recent analysis of shareholder ratification in Gantler v. Stephens. ${ }^{75}$ There, the defendants argued that the same shareholder vote was effective both to amend the corporation's certificate of incorporation in order to effect a share reclassification, and to "ratify" the conduct of the corporation's directors-a majority of whom were interested in the outcome of the reclassification. ${ }^{76}$ In Gantler, the court held that a shareholder vote constitutes "ratification" only when its subject is an action by directors that does not legally require shareholder action, as amending the certificate unquestionably does. ${ }^{77}$ And "the only director action or conduct that can be ratified is that which the shareholders are specifically asked to approve."78 Double-counting the effect of the shareholder vote would risk distorted outcomes that confound shareholder support for a transaction, which may reflect an assessment of the available alternatives, with the process or conduct associated with the transaction, including breaches of fiduciary duties. Like ratification within agency law, Gantler requires specificity and focus in conditioning the efficacy of a shareholder vote on whether the shareholders were fully informed. ${ }^{79}$ On the Gantler facts, although the proxy statement disclosed the directors' conflict of interest regarding the reclassification, it did not disclose that they engaged in little or no deliberation over a third-party merger proposal. Instead, according to the proxy statement the board deliberated carefully, which undermined the defendants' argument that the shareholder vote was fully informed. ${ }^{80}$ In other words, simply disclosing that the members of the board had conflicts of interest in how they structured the reclassification was not effective disclosure of the historical fact that the board did not deliberate carefully. ${ }^{81}$ In short, these recent examples illustrate corporate law doctrine's sensitivity to fundamental distinctions and requirements that closely resemble those of agency law.

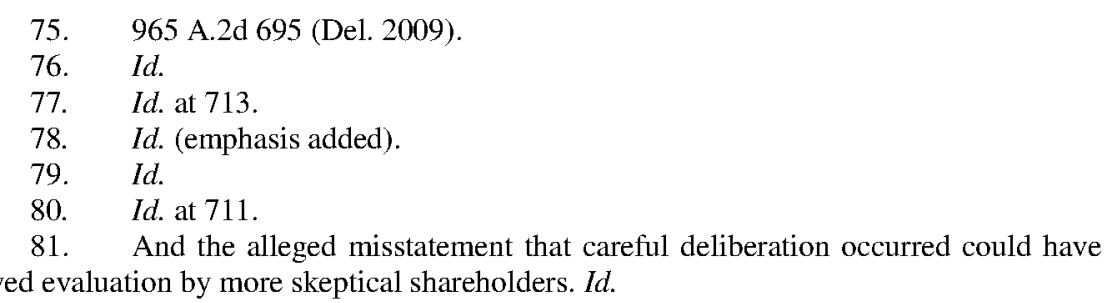




\section{REVISITING THE ANALYSIS OF FoRUM-SELECTION BYLAWS}

\section{A. Terminology and Concepts as Evolution Proceeds}

As the court observed in Edgen, what to make of forum-selection provisions in corporate bylaws and charters is "an evolving issue." 82 One sign that this is a work-in-progress is the inconsistent terminology used in both judicial opinions and scholarly commentary. ${ }^{83}$ As a consequence, at least viewed from the perspective afforded by agency law, the rationales and concepts in play can be elusive. Areas that require clarification include: (1) the extent to which the legitimacy of directors' unilateral adoption of a forum-selection bylaw is a consequence of power conferred by the statute or closer to an agency-like (or "lite"?) delegation by shareholders; and (2) the nature of shareholders' consent to the bylaw and their knowledge concerning it.

\section{Power, Authority, and Legitimacy}

Analyses of forum-selection bylaws seem to use the terms "power" and "authority" interchangeably, which calls into question the rationale that legitimates directors' actions concerning bylaws. The DGCL's language is: "power" to adopt, amend, and repeal bylaws, which the certificate of incorporation may "confer... upon" on directors. ${ }^{84}$ Consistent with the statutory language, the opening paragraph in Boilermakers states that both defendants' boards "have been empowered in their certificates of incorporation to adopt bylaws under" the statutory provision. ${ }^{85}$ However, later in the opinion, the same certificates are said to "authorize their boards to amend the bylaws." The court concluded that bylaws "form part of a flexible contract between corporations and stockholders, in the sense that the certificate of incorporation may authorize the board to amend the bylaws' terms ... ." 86 To a scholar of agency law, terms like "authority" operate as visual catnip to connote some sort of agency relationship between shareholders and directors, but perhaps the shifts in usage in the opinion are simply variations in wording intended to be synonymous.

On the other hand, if it's attractive to designate what the board holds as "authority" concerning bylaws, this may be because the language of authority-in a nonagency or agency-lite sense-seems a better fit with the argument that shareholders are parties to a "flexible contract," of which directors' control over

82. Transcript of Oral Ruling at 42, Edgen Grp. Inc. v. Genoud, No. 9055-VCL, 2013 WL 6409517 (Del. Ch. Nov. 5, 2013). See also Joseph A. Grundfest \& Kristen A. Savelle, The Brouhaha Over Intra-Corporate Forum Selection Principles: A Legal, Economic, and Political Analysis, 68 Bus. LAw. 325, 352 (2013) (defending forumselection provisions on many scores but acknowledging that they are not "without their own costs, particularly in the early years of their adoption and enforcement while the judicial system is still working through the learning curve by developing precedent governing the implementation of these novel provisions").

83. See infra text accompanying notes $85-90$.

84. Del. Code Ann. tit. 8, § 109(a) (2014).

85. Boilermakers Local 154 Retirement Fund v. Chevron Corp., 73 A.3d 934, 937 (Del. Ch. 2013).

86. Id. at 939 . 
bylaws is one component, and to which shareholders "assent to be bound ... when they buy stock ...." ${ }^{87}$ The language of "authority," that is, seems to work better than "power" in a legitimating framework that connotes private ordering. ${ }^{88}$ When coupled with the "flexible contract" argument, "authority" may also imply that it is the shareholders themselves who have situated the corporation's directors relative to control over bylaws. This logic de-emphasizes prescription by the state through the statute in favor of framing the question within a context dominated by privateparty consent.

Alternatively, as suggested by Professor Joseph Grundfest and Kristen Savelle in their leading scholarly defense of forum-selection bylaws, perhaps it is the DGCL itself that confers "authority." Grundfest and Savelle propose that such provisions could be "framed as relating to the powers and rights of the corporation's directors and officers, as distinct from the stockholders." They assert that reframing would better focus on "the relationship between the authority delegated to manage the corporation's affairs" in the basic DGCL provision that prescribes the board of directors' position, and "the scope of permissible bylaw provisions." ${ }^{89}$ It's unlikely that this passage was intended to imply that the state of Delaware itself, or some personalization of Delaware's corporation statute, should be viewed as the principal in an agency relationship with boards of directors to whom "authority" is "delegated." 90 Instead, harkening to the statute as the source of the power over bylaws that directors may receive through a certificate provision appears to emphasize less the rationale of the "flexible contract" to which shareholders become parties and to highlight the role of the state acting through the statute.

\section{Shareholders' Consent and Knowledge in Boilermakers}

Situating directors' adoption of forum-selection bylaws within a context of private ordering requires some account of the mechanism through which shareholders consent, in addition to the state of their knowledge. The Boilermakers opinion uses the language of "assent" to introduce the terminology of the flexible contract to which shareholders assent when they buy stock. ${ }^{91}$ Likewise, the

87. Id.

88. Grundfest \& Savelle, supra note 82, at 351 (characterizing forum-selection provisions as "rely[ing] on private ordering to attempt to cause intra-corporate litigation to be aggregated in the chartering state in a manner that protects stockholder rights").

89. Id. at 374 . The statutory provision provides that "[t]he business and affairs of every corporation organized under this chapter shall be managed by or under the direction of a board of directors, except as may be otherwise provided in this chapter or in its certificate of incorporation." DEL. CODE ANN. tit. 8, $\S 141$ (a). The statutory management power held by boards is, in theory, in tension with shareholder-adopted bylaws that restrict or limit the board's power, but the "expressly inviolate" bylaw power that $\S 109$ (a) invests in shareholders requires the validity of shareholder-enacted bylaws regulating appropriately process-related issues. CA, Inc. v. AFSCME Emp. Pension Plan, 953 A.2d 227, 234 (Del. 2008). However, if the bylaw could mandate that directors breach their fiduciary duties, it is invalid. $I d$. at 240.

90. Grundfest \& Savelle, supra note 82 , at 374.

91. Boilermakers Local 154 Retirement Fund v. Chevron Corp., 73 A.3d 934, 956 (Del. Ch. 2013). 
defendants" shareholders "assented to a contractual framework established by the DGCL and the certificates of incorporation that explicitly recognizes that stockholders will be bound by bylaws unilaterally adopted by their boards." 92 The initial assent implied that the shareholders did not have "to assent to board-adopted bylaws," and is part of a contractual framework "chosen" when the stock is purchased. ${ }^{93}$ As stated in Boilermakers, at the time the investors purchased the stock, they knew of the scope of directors' bylaw powers based on the charter's grant of those powers on the board..$^{94}$

The elaboration of consent and knowledge embodied in agency doctrine earlier in this Article helps explain why Boilermakers's reasoning is not universally persuasive. For starters, in Galaviz v. Berg, the first opinion from a non-Delaware court assessing a forum-selection bylaw adopted unilaterally by a board, the court held that mutual consent is "the essential element," and that it is required to warrant enforcing a bylaw as comparable to a contractual forum clause ${ }^{95}$ Federal common law governed the enforceability of a limit on suing in an otherwise-permissible venue and, the court noted, the defendant had identified no basis on which a federal court should defer to any provision of state corporate law-like its treatment of bylaws-"that might purport to give a corporation's directors the power to control venue" when they were named as defendants in the derivative action filed by the plaintiffs. ${ }^{96}$ According to the Boilermakers court, the Galaviz court reached this conclusion because it failed to "appreciate the contractual framework" established by the Delaware corporation statute. ${ }^{97}$ But perhaps the Galaviz court understood "contractual" to require less attenuated forms of consent, especially when one party to a "contract"-however flexible-has power to alter the legal position of another who is party to the contract merely due to generic governance provisions. Likewise, perhaps the Galaviz court assumed that the traditionally "process-creating function" of bylaws ${ }^{98}$ limits their reach to the corporation's internal, self-created processes and that, on reflection, terming something "contractual" did not situate it within a plausible account of contract law. ${ }^{99}$

92. Id.

93. Id.

94. Id. at 941 .

95. 763 F. Supp. 2d 1170, 1174 (N.D. Cal. 2011). See also Thomas, supra note 37 , at 1954 (characterizing analogy to contract law as "not conclusive" because forumselection clauses "implicate corporate governance and disadvantage shareholder efforts to engage in rigorous monitoring of management agency costs").

96. Galaviz, 763 F. Supp. 2d at 1175.

97. Boilermakers, 73 A.2d at 956.

98. See CA, Inc. v. AFSCME Emp. Pension Plan, 953 A.2d 227, 235 (Del. 2008).

99. As Professor Radin stated, "one cannot (except in Humpty-Dumpty's world) make something into an agreement merely by using that word." MARGARET JANE RADIN, BOILERPLATE 82 (2013). And "agreement' ... is the traditional word used for a contract..." Id. Professor Radin's implicit reference is to a well-known fictional encounter. When Lewis Carroll's fictional creation, Alice, first encounters Humpty Dumpty, he declares it "very provoking . . . to be called an egg." LEwIS CARROLL, THROUGH THE LOOKING Glass 365 (1896). Alice is puzzled by Humpty Dumpty’s insistence that the 
The common law framework that defines and governs an agency relationship is an analogous instance of initially assenting to "not having to assent" to subsequent actions taken by the agent that fall within the scope of the agent's actual or apparent authority when the agent has even a small modicum of discretion. But the touchstone for an agent's exercise of discretion is the agent's reasonable assessment of the principal's preferences at the time the agent acts. ${ }^{100}$ While many separate components of agency doctrine reflect the likelihood that an agent is likely to have knowledge superior to that of the principal, it is the principal's reasonably knowable preferences that should govern the agent's exercise of discretion. Moreover, the agency-doctrine framework is not likely to indulge in an agent's novel interpretation of the extent or nature of authority granted by the principal. This is similar to how an agent is constrained from acting in accord with trade practices or customs if the practices are unknown to the agent and, if the agent followed them, would lead to results the principal would not wish. The agency doctrine is careful concerning assertions about knowledge. To be sure, a principal could always be said to "know" that the agent might do something the principal neither contemplates nor would wish to happen, but just as in Seinfeld, that prospect of hypothetical insight does not count as knowledge. ${ }^{101}$

There are two other contrasts between corporate law and agency doctrine that are worth noting. First, as emphasized by both Boilermakers and academic commentators, shareholders who disagree with a board's adoption of a forumselection bylaw may use their parallel bylaw power to repeal or amend it. ${ }^{102}$ This argument does not acknowledge that, to exercise their bylaw powers, shareholders act within a set of constraints. These constraints include limits on their power to call meetings or act by written consent, plus practical hurdles to obtaining the support of fellow shareholders in sufficient numbers. ${ }^{103}$ Alternatively, if these constraints are rationalized as components of the "flexible contract" that shareholders are deemed to know when they invest, one wonders what the bounds or scope of the contract might be. In contrast, a principal in a common law agency relationship has the power to terminate the relationship, even when doing so breaches a contract with the agent. Further, the principal in a common law agency relationship can also intervene through its ongoing power to furnish instructions to

word 'glory' means 'a nice knock-down argument;' but Humpty Dumpty then declares, "[w]hen $I$ use a word . . . it means just what I choose it to mean-neither more nor less." Id. Humpty Dumpty is often viewed as a "monster of private language," surreptitious and arbitrary in how he uses words. See Michael Hancher, Humpty Dumpty and Verbal Meaning, 40 J. AEsTHETICS \& ART CRITICISM 49 (1981). More sympathetically, he may be a practitioner of stipulative definition, operating on his own private definitions, who defines terms (to Alice) after he uses them. Id. at 50. This odd sequence is consistent with his own side of the looking glass, in which time is reversed. Id.

100. For a full elaboration of this point, see Deborah A. DeMott, The Fiduciary Character of Agency and the Interpretation of Instructions, in PHILOSOPHICAL Foundations of Fiduciary Law 321 (Andrew S. Gold \& Paul B. Miller eds., 2014).

101. Seinfeld v. Slager, No. 6462-VCG, 2012 WL 2501105, at*12 (Del. Ch. Apr.

25, 2012)

102. Boilermakers, 73 A.3d at 956; Hamermesh, supra note 24, at 170 .

103. Thomas, supra note 37 (detailing "substantial collective action problems" that shareholders would confront). 
the agent that can countermand actions the agent would otherwise be authorized to take. ${ }^{104}$

Second, Boilermakers emphasizes the strength of Delaware's equitable precedents that enable the court to engage in after-the-fact review of a fiduciary's use of power. ${ }^{105}$ For example, in Moran $v$. Household International, Inc., the Delaware Supreme Court legitimated a board's novel use of its power to configure and issue preferred stock as a defense against hostile-takeover bids, pairing this power with a commitment to ex post review when the board determined whether to redeem the stock to enable a bid to proceed. ${ }^{106}$ Agency doctrine, in contrast, does not rely on after-the-fact review into substantive merits to determine whether a principal is bound by an action for which an agent lacked authority. ${ }^{107}$ Therefore, if an agent purports to commit the principal to arbitrate any disputes arising from transaction or relationship with a third party, when the agent lacked actual or apparent authority so to bind the principal, then the court does not inquire into the merits of the transaction or relationship. ${ }^{108}$ The resolution is categorical and much simpler: the principal is not bound by an agreement to arbitrate that the agent lacked authority to make on the principal's behalf. Agency doctrine, in short, can draw clean lines, in contrast to after-the-fact review into the circumstances under which power was used.

\section{B. The Singularity of the "Flexible Contract"}

As discussed earlier, the Edgen court differentiated between "negotiated agreements" and other contexts in which parties who are not direct signatories are alleged to be subject to forum-selection provisions. ${ }^{109}$ Negotiated agreements occupy a specific domain-in contrast, everyday contracts for most people are not "negotiated agreements," and yet are still enforceable. The contractual landscape of everyday life is dominated by boilerplate, not negotiated terms. Boilerplatedefined consumer contracts stem from transactional processes characterized by one leading scholar as "shopping (rather than bargaining) behavior . . ." 110 Within this

104. RestatemENT (THIRD) OF AGENCY $\S 1.01$, cmt. f(1) (2006).

105. 73 A.3d at 949.

106. 500 A.2d 1346 (Del. 1985) (discussed in Boilermakers, 73 A.3d at 953).

107. RESTATEMENT (THIRD) OF AGENCY, ch. 2, intro. note.

108. See, e.g., Hogsett v. Parkwood Nursing \& Rehab. Ctr., Inc., 997 F. Supp. 2d 1318 (N.D. Ga. 2014) (patient never agreed to representation by daughter who signed arbitration agreement when patient admitted to nursing home). See also Askenazy v. KPMG LLP, 988 N.E.2d 463 (Mass. App. Ct. 2013) (under Massachusetts and New York law, a nonsignatory to a contract may be compelled to arbitrate claims only when nonsignatory's conduct manifests an intent to be bound by arbitration provision in contract; extracontractual claims asserted by fund investors against auditor not subject to arbitration when claims were direct, not derivative of fund's claims, and nothing in record demonstrated investors' intent to be bound by fund's engagement letters with auditor, which included mandatory arbitration provisions).

109. Edgen Grp. Inc. v. Genoud, No. 9055-VCL, 2013 WL 6409517 (Del. Ch. Nov. 5, 2013).

110. Todd D. Rakoff, Contracts of Adhesion: An Essay in Reconstruction, 96 HARV. L. REV. 1174, 1226 (1983). To be sure, "shopping" for terms in the mass-market consumer setting can be "daunting." See Oren BAR-GIll, Seduction By Contract: Law, 
landscape, "shoppers" only rarely read the terms of the contractual documents that bind them. Additionally, for some contracts-like software shrink-wrap agreements - certain terms are not even available for reading until the shopper opens the packaging. This transforms contract formation itself into a "rolling" process, raising serious doubts about its fit within more conventional understandings both of contract formation and of assent to later-arriving terms. ${ }^{111}$ Regardless, the defining features of the "flexible contract" make it a singular instance $^{112}$ - even when viewed alongside the unlikely-to-be-read language of prototypical consumer contracts, some of which are arguably formed on a rolling basis.

For starters, just as forming an agency relationship leads to legally distinct consequences, making an equity investment does not seem reducible to either "bargaining" or "shopping" behavior that culminates in the purchase of goods or a service. Equity ownership implicates a legally significant suite of governance relationships that includes the directors' and other corporate actors' fiduciary duties. Only a commitment to a radical form of conceptual reductionism could justify overlooking these consequences. ${ }^{113}$

Additionally, in contrast to prototypical consumer boilerplate, the "flexible contract" lacks specificity, ${ }^{114}$ which calls into question whether a shareholder has sufficient notice of any particular downstream consequence that may follow from directors' use of general bylaw powers. It is not counterintuitive to think that a person might consent to contractual terms when unaware of their contents, as by clicking an "I agree" button on a website. ${ }^{115}$ Consider a hypothetical posed by Professor Randy Barnett:

Suppose I say to my dearest friend, "Whatever it is you want me to do, write it down and put it into a sealed envelope, and I will do it for you." Is it categorically impossible to make such a promise? Is there something incoherent about committing oneself to perform an

ECONOMICS, AND Psychology IN CONSUMER MARKETS 3 (2012) (characterizing task of choosing among complex, multidimensional cell-phone contracts).

111. See, e.g., Colin P. Marks, Not What, But When Is an Offer: Rehabilitating the Rolling Contract, 46 ConN. L. REv. 73 (2013); Murray, supra note 20.

112. The common law "does not officially acknowledge that different categories of contracts are treated differently by the law," in contrast to civil-law systems which recognize categories of "special' or 'nominate' contracts ...." STEPHEN A. SMITH, CONTRACT THEORY 312 (2004).

113. On the error of looking to contract for an account of fiduciary relations, see Daniel Markovits, Sharing Ex Ante and Sharing Ex Post: The Non-Contractual Basis of Fiduciary Relations, in PHILOSOPHICAL Foundations of FdDUCLARY LaW 211 (Andrew S. Gold \& Paul H. Miller eds., 2014).

114. If anything, consumer boilerplate has too much specificity and thus consumers do not read it. But it's there to be read even when it arrives later on.

115. Scholars of contract law differentiate these situations -in which consent is problematic-from ones of nonconsent, in which "we either don't know that something is happening or do know that something is happening but do not know the significance of what is happening." RADIN, supra note 99, at 22. No recognizable sense of "agreement" captures, for example, the mere act of walking past a sign. Andrew S. Gold, Contracts With and Without Degradation, 40 CAP. U. L. REV. 657, 661 (2012). 
act the nature of which one does not know and will only learn later? ${ }^{16}$

Professor Barnett's answer is "no." He argues that that the promise to the dearest friend is a real one, and that what is true of it establishes the reality of consent in the context of form contract-that consent is best understood as making a promise that is "nested within an overall consent to be legally bound." 117 To be sure, whether this argument is persuasive depends on one's theory of consent (and of contract), but the account is plausible. ${ }^{118}$ The same account would also encompass "consent[ing] to surprises," whether the outcome of a lottery or the terms of the contract itself. ${ }^{119}$ But notice the singularity of the "flexible contract" even in light of these comparisons. The downside risks associated with buying a lottery ticket are: limited to not winning a prize; known at the time of the purchase; and comprehensible by any rational ticket purchaser. Additionally, notice that the speaker's promise to the "dearest friend" is to perform whatever the friend specifies in the writing in the sealed envelope, not a temporally unbounded commitment to do whatever the friend may want, whenever the wish is conveyed to the speaker. And, of course, the speaker is not entrusting the friend, however dear she might be, with control over the speaker's property, nor does the speaker attempt to make the dearest friend her agent by saying: "I will be bound by whatever legal obligations you choose to incur on my behalf." 120

Moreover, like other scholars whose accounts domesticate consumeragreement boilerplate into the realm of consensual contracts, Professor Barnett imposes limits—specifically: "a qualification implicit in every such manifestation of consent to be legally bound," which he calls the "your favorite pet" qualification." 121 Consent as it exists in the context of clicking "I agree" encompasses only consent to terms that are not "radically unexpected," as an instruction to transfer one's favorite pet would be. ${ }^{122}$ Other scholars delimit the boundary of consent to unknown terms to situations in which notice is provided

116. Randy E. Barnett, Consenting to Form Contracts, 71 FordHAM L. REv. 627, $636(2002)$

117. Id.

118. Gold, supra note 115 , at 662 .

119. Id. at 663. On the lottery example, see Omri Ben Shahar, The Myth of the 'Opportunity to Read' in Contract Law, 5 EUR. REV. CONT. L. 1, 9 (2009) (discussed in Gold, supra note 115 , at 662).

120. By itself this statement would not create a relationship of agency because the dearest friend has not manifested assent to such a relationship. Additionally, the speaker (as principal) appears not to have any right or power to control the dearest friend, and the dearest friend appears not to be subject to anything resembling a fiduciary obligation to the speaker. See supra text accompanying note 30. Any relationship of agency that resulted would be fragile, subject as it would be to the speaker's ongoing power to terminate the dearest friend's actual authority. See supra text accompanying note 33 . That the actor is the speaker's dearest friend and not a stranger may not undermine the presence of consent but raise concerns about whether the consent warrants enforcing the promise. See Gold, supra note 115 , at $665-66$.

121. Barnett, supra note 116 , at 637.

122. Id. 
that additional terms will be forthcoming. ${ }^{123}$ Or, alternatively, to notice that additional terms lurk within the package containing the goods, which the purchaser should return for a full refund if not satisfied with the terms after opening the package and reading them. ${ }^{124}$ In contrast, the "flexible contract" in Boilermakers is not subject to the categorical specifications or qualifications required by massmarket boilerplate theorists - given the relative per-transaction stakes, this contrast is startling. Once a shareholder learns that the board has adopted a forum-selection bylaw, she could sell the stock if there is a market for it, but that is not the equivalent of returning goods for a refund of the price. ${ }^{125}$ Thus, the flexible contract is a singular construct, unmoored from both contract and agency principles.

Finally, as discussed in the Introduction, the consequences of contractualized governance arrangements in noncorporate entities are disconcerting, at least to some observers. Noncorporate entity investors have no choice but to acquiesce to terms imposed by entity sponsors, terms that purported to vitiate or eliminate the fiduciary duties of entity managers. Although that context differs from the "flexible contract" regime for corporate bylaws, in both settings the rhetoric of "contract" does not match well with the underlying reality, which includes the existence of unilaterally adopted or imposed governance terms that were neither bargained for nor consented to by the investors whose rights they eliminated or weakened.

\section{IMPLICATIONS}

So far, this Article has argued that forum-selection bylaws rest on attenuated and implausible conceptions of shareholder consent and knowledge, a result not mitigated by the construct of the "flexible contract" announced in Boilermakers. Not only does the "flexible contract" justify outcomes at odds with agency doctrine, it clashes with conventional understandings of contract doctrine. Additionally, as noted above, its legitimation may tempt even more aggressive uses of the bylaw power. ${ }^{126}$ As a consequence, revising the DGCL warrants

123. Marks, supra note 111 , at 104.

124. Murray, supra note 20, at 77-78.

125. Nor is it the equivalent of the "walk-away power" held by a nondrafting party. For this terminology, see Andrew Robertson, The Limits of Voluntariness in Contract, 29 MELB. U. L. REV. 179, 194 (2005). Additionally, sellers of goods in this situation have been characterized as situation-specific monopolists in relationship to customers who have already purchased the goods. Russell Korobkin, Bounded Rationality, Standard Form Contracts, and Unconscionability, 70 U. CHI. L. REV. 1203, 1265 (2003). Professor Korobkin theorizes that this position gives sellers an incentive "to try to capture benefits of their monopoly position by providing low-quality terms" since the agreed-to price itself has already been paid. $I d$.

126. See supra text accompanying note 24 . Whether by using the "contract" terminology Boilermakers made it more difficult to cabin bylaws mandating the use of arbitration- "contracts" to arbitrate being the gateway to application of the Federal Arbitration Act-is beyond the scope of this Article. See generally Allen, supra note 24 (discussing, inter alia, recent and expansive interpretations of the Federal Arbitration Act 
consideration. In this context, an overarching justification for jettisoning the "flexible contract" in favor of statutory specification is to emphasize that limitations and restrictions on bylaw powers are constitutive of any corporationthat is, integral to the corporation as a distinct legal person-formed under that statute. This ties restrictions on directors' bylaw power to the internal affairs doctrine, ${ }^{127}$ as well as distances them from state-law contract doctrines like unconscionability. ${ }^{128}$

More specifically, statutory treatment of forum-selection bylaws would acknowledge the importance of implied consent in corporate law by creating a basis to determine when shareholders have been put on notice of such bylaws. That is, much in corporate law turns on implied consent, including the basic majoritarian norm of shareholder voting. ${ }^{129}$ But implied consent goes only so far. The current position of shareholders in Delaware corporations may be uncomfortably close to that of officers and directors in an earlier era in which Delaware treated stock ownership as a sufficient basis for the exercise of personal jurisdiction. That is, agreeing to accept a fiduciary position, when coupled with stock ownership, constituted implied consent to being haled into court in Delaware via Delaware's sequestration procedure even when ownership of the stock itself was not the focus of the litigation. ${ }^{130}$ In Shaffer $v$. Heitner, the Supreme Court held that this use of in rem sequestration as a vehicle to secure personal jurisdiction violated the Due Process Clause. ${ }^{131}$ In a concurring opinion, Justice Stevens wrote that "[o]ne who purchases shares of stock on the open market can hardly be expected to know that he has thereby become subject to suit in a forum remote from his residence and unrelated to the transaction." 132 Further, to Justice Stevens, minimizing the risks of broadly drawn implied consent was not without costs to investors because "unless the purchaser ascertains both the State of incorporation of the company whose shares he is buying, and also the idiosyncrasies of its law, he may be assuming an unknown risk of litigation." 133

In contrast, the statutory amendment that followed Shaffer-DEL. CoDE ANN. tit. 10, §3114-both explicitly asserts Delaware's interest in securing

by the Supreme Court and questioning their applicability "to a different type of contract"); Ann Lipton, Manufactured Consent: The Problem of Arbitration Clauses in Corporate Charters and Bylaws, 104 GEO. L.J. _ (forthcoming 2015), available at http://ssrn.com/abstract=2572014.

127. For a general statement of the doctrine, see RESTATEMENT (SECOND) OF CONFLICT OF LAWS \& 302(2) (1971) (local law of corporation's state of incorporation applicable to questions that do not involve rights or obligations of third parties). In Delaware, the doctrine has been characterized as one of "serious constitutional proportions." See McDermott, Inc. v. Lewis, 531 A.2d 206, 216 (Del. 1987).

128. See AT\&T Mobility L.L.C. v. Concepcion, 131 S. Ct. 1740 (2011) (Federal Arbitration Act preempts California contract law doctrine of unconscionability applicable to class action waivers in consumer contracts).

129. See supra note 37.

130. Shaffer v. Heitner, 433 U.S. 186 (1977). See also supra note 16.

131. 433 U.S. at 215.

132. Id. at 218 .

133. $I d$. at 219 . 
jurisdiction over corporate fiduciaries, ${ }^{134}$ and creates a firmer basis for implied consent. Thus a mirror-image of $\$ 3114$ applicable to shareholders is one possibility to consider and evaluate. To be sure, $\S 3114$ is not a perfect analogy for a statutory exclusive-forum provision applicable to shareholders. Applicable to directors and officers, $\$ 3114$ itself is a fact that can be known before a person agrees to serve as a director or officer, and if not actually known by any particular prospective director or officer, is something that his or her lawyer should know and, like the prospective fiduciary, could know. ${ }^{135}$ This would also be true for a mirror-image statute applicable to shareholders. However, consistent with the insights of Justice Stevens, simply buying shares (particularly in a publicly traded corporation) may be different. An investor with an active and diversified portfolio and her advisors could confront wide-ranging research into state-law idiosyncrasies, in contrast to the more limited research to be done by prospective fiduciaries. Nonetheless, a mirror-image of $\$ 3114$ applicable to shareholders would overcome the imponderable quality of notice that dogs the "flexible contract," which presupposes notice of a fact that is not presently discernible. But the mirror-image of $\$ 3114$ would leave open the concern that for some investors notice would remain an artificial construct due to the relative magnitude of the requisite research.

Alternatively, the DGCL might be amended both explicitly to enable the adoption of forum-selection bylaws, as well as to introduce limits and requirements applicable to them. For example, were the DGCL amended to require shareholder approval for forum-selection bylaws, any bylaw so adopted would become a matter of public record, comparable to a provision in an original or restated certificate of incorporation. ${ }^{136}$ Additionally, an amendment to the DGCL could limit the effectiveness of a bylaw adopted unilaterally by directors to shareholders who thereafter acquire stock so long as the corporation creates a public record of the bylaw through a filing with the Secretary of State. Separately, the history of Del. Code Ann. tit. 8, $\S 102(\mathrm{~b})(7)$ is relevant because it enabled the adoption of certificate provisions that exculpate directors against monetary liability for breaches of their duty of care. ${ }^{137}$ Amending the DGCL to add $\$ 102(b)(7)$

134. The absence of such a statute was singled out by the majority opinion in Shaffer as undercutting what was asserted to be the necessity of using in rem sequestration to secure personal jurisdiction over corporate fiduciaries to further the state's "strong interest in supervising the management of a Delaware corporation." Id. at 214-15 "If Delaware perceived its interest in securing jurisdiction over corporate fiduciaries to be as great as [plaintiff] suggests, we would expect it to have enacted a statute more clearly designed to protect that interest.").

135. DEL. CODE ANN. tit. 10, $\$ 3114$.

136. This would overcome objections of proxy-advisory firms and institutional investors that generally oppose forum-selection provisions adopted post-IPO and without a shareholder vote. See Allen, supra note 24. See also Is It Time to Adopt a Forum Selection Bylaw?, AKIN GUMP Strauss HAUER \& FELD LLP (June 28, 2013), available at http://cdn.akingump.com/images/content/2/3/v4/23771/104880825=1.pdf (reporting policies of Council of Institutional Investors and AFL-CIO, which oppose adoption of forumselection provisions; proxy advisory firms generally oppose the provisions and require evidence of compelling circumstances to relax opposition on case-by-case basis).

137. See supra note 23. 
obviated questions about the effect of exculpatory provisions not enabled by statute by framing exculpation as a question governed the DGCL itself. Section $102(b)(7)$ also, through exclusions, regulates the extent to which directors may be exculpated from liability. And, by permitting exculpatory provisions only in certificates of incorporation, the section foreclosed the bylaw route. An exculpatory provision requires a shareholder vote to amend the corporation's certificate of incorporation if not present in a corporation's initial certificate of incorporation. Either way, a public record of the provision follows because the certificate is a public document filed with the secretary of state, creating a conventional mechanism for implied consent by shareholders. ${ }^{138}$ This route is open to the potential objection that prospective shareholders would be subject to the burden of additional research into governance characteristics of particular companies, but at least the relevant information would be discernible from public sources. $^{139}$

\section{CONCLUSION}

A final perspective on the salience of agency-derived concepts is evident in light of macro-level changes in the composition of equity ownership in U.S. public corporations. Inexorably it seems, over the last few decades markets have experienced "deretailization" through concentrated institutional ownership and shifts toward mutual funds from corporate defined-benefit pension plans. ${ }^{140} \mathrm{~A}$ significant consequence is a shift to shareholder-centricity on many issues, including executive compensation and the composition and outlook of corporate boards, ${ }^{141}$ a shift that was not the direct consequence of legal change. ${ }^{142}$

138. For an earlier proposal along these lines, see Brian J.M. Quinn, Shareholder Lawsuits, Status Quo Bias, and Adoption of the Exclusive Forum Provision, 45 U.C. DAVIS L. REV. 137, 182-91 (2011) (proposing draft language for a new DEL. CODE ANN. tit. 8, $\S 102(b)(8))$. Professor Quinn's proposed amendment does not include consent-tojurisdiction language. As the Edgen court acknowledged, the assertion of personal jurisdiction may constitutionally require more than owning stock in a Delaware corporation. See supra text accompanying note 15 . On the other hand, the corporation's certificate of incorporation in Edgen did not address personal jurisdiction over shareholders, which leaves open the question of the validity of consent-to-jurisdiction language contained in certificate provisions.

139. In another context, the Court of Chancery recently acknowledged that "it would be unreasonable to expect stockholders to monitor the Secretary of State's filing system, pay to obtain each new filing, and scour it for evidence of potential injury[,]" in a dispute focused on the availability of equitable tolling against the limitations period applicable to an alleged breach of fiduciary duty stemming from a reverse stock split and the defendants' exercise of a right to redeem the plaintiffs' preferred stock. See Carsanaro v. Bloodhound Techs., Inc., 65 A.3d 618, 646 (Del. Ch. 2013) (applying equitable tolling, and noting that to the extent the plaintiffs had taken initiative to obtain filings, the relevant filings would not have placed plaintiffs on notice that the principal purchasers in the transaction were the corporation's directors and their affiliates).

140. Rock, supra note 32, at 1922. Professor Rock credits the "deretailization" term to Brian Cartwright, who at the time he named the phenomenon and highlighted its regulatory significance was the SEC's General Counsel. Id.
141. Id. at 1910. 
Nonetheless, in some scholarly assessments, corporate law in the United States (unlike its counterparts in some other major jurisdictions) retains an orientation toward a managerialist world and lags in responding to macro-level shifts in equity ownership. ${ }^{143}$ The chilly reception that forum-selection provisions received from proxy-advisory firms and some institutional investors ${ }^{144}$ may underscore that the relationship between corporate law and macro-level developments in markets will always be "an evolving issue," like more formal developments in the legal status of forum-selection bylaws. A lagged reorientation of corporate law to a reality of greater shareholder-centricity may or may not be desirable but its intellectual underpinnings would be more closely allied with agency doctrine.

142. Id.; accord Martin Gelter, The Pension System and the Rise of Shareholder Primacy, 43 Seton Hall L. ReV. 909, 917-20 (2013).

143. Gelter, supra note 142, at 920; Christopher M. Bruner, Power and Purpose in the "Anglo-American" Corporation, 50 VA. J. INT'L L. 579, 593-603 (2010); Rock, supra note 32, at 1978.

144. See supra text accompanying note 6 . 
